\title{
The Byzantine Eastern Church of Khirbet et-Tireh
}

\author{
Salah Hussein A. Al-Houdalieh \\ The Institute of Archaeology, Al-Quds University, Palestine \\ Email: shoudalieh@art.alquds.edu
}

Received 14 December 2015; accepted 26 January 2016; published 29 January 2016

Copyright (C) 2016 by author and Scientific Research Publishing Inc.

This work is licensed under the Creative Commons Attribution International License (CC BY). http://creativecommons.org/licenses/by/4.0/

(C) (7) Open Access

\begin{abstract}
Khirbet et-Tireh was inhabited during the Hellenistic, Roman, Byzantine and Early Islamic periods, and was later used as agricultural land throughout the Ottoman-Turkish period and down to modern times. The ancient settlement has been determined to cover a total area of approximately $\mathbf{3 0 , 0 0 0}$ square meters. However, 75 percent of its historic fortified space has been destroyed over the past few decades by the construction of roads, a school, a gas station and several residential structures on its northern part. The surviving architectural remains at the Khirbet include a system of fortifications, a Byzantine monastery, two Byzantine-era churches, a rock-cut reservoir, a cistern, water channels, a rock-cut olive press, several burial caves, a street (or a wide pathway corridor), and several dry-stone terrace walls. The unearthed part of the eastern church complex measures $28.8 \mathrm{~m}$ long along its east-west axis and a maximum of $25.5 \mathrm{~m}$ wide in its north-south dimension. It follows a basilical plan and consists of five main parts: four south side rooms, an atrium, a narthex, a main hall, and three northeast side rooms. The entire area of the church was once paved with mosaic carpets consisting of geometric and figurative designs, with the richly colored tesserae encompassing various shades of white, black, grey, yellow, orange, pink, wine red, green and blue. Furthermore, remains of two plaster layers were uncovered on the interior faces of the majority of the walls of the church complex. After the final consolidation and conservation of the mosaic pavements of the church, as a protective measure we are covering the mosaics with a permeable, plastic-mesh geotextile, topped by a layer of sieved soil $0.25 \mathrm{~m}$ thick.
\end{abstract}

\section{Keywords}

Khirbet et-Tireh, Church, Crypt, Mosaics, Byzantine Period

\section{Introduction}

Khirbet et-Tireh (or et-Tira, el-Tira, al-Tira) is situated some $1.5 \mathrm{~km}$ west of the historic centre of the West 
Bank city of Ramallah and approximately 16 km northwest of Jerusalem (Figure 1). It is located adjacent to the Ramallah Women's Training Centre, a United Nations Relief and Works Agency facility, and very near the St. George School. The larger et-Tireh site-the northern part of which has been developed and built over in modern times-covers the summit and slopes of a small hill at an elevation of $804 \mathrm{~m}$. This vantage point commands a wide vista of areas to the north and west, but the view toward the south and east is obstructed by surrounding hills higher in elevation. The ancient settlement has been determined to cover a total area of approximately 30,000 square meters. The best preserved part of the settlement, the focus of our various studies, constitutes an area of about 6000 sq. meters located at the southern end of the larger site. Here the property is owned entirely by the Greek Orthodox Church, through their Patriarchate. The northern part of the site, however, (across the modern paved road) is all located on private property belonging to various individuals and organizations and, as mentioned, the remains there have been either heavily damaged, destroyed or otherwise obscured due to development (Al-Houdalieh, 2014: p. 188-189).

Three excavation campaigns have thus far been conducted on the Greek Orthodox property. This work, under the direction of the author, was carried out during the summers of 2013 to 2015, for a total of 20 weeks of work on-site. By the end of the third campaign, our teams, ranging from 22 to 29 individuals, had excavated a total area of approximately 1600 square meters (Figure 2). In most of the excavated squares, soundings went down to the level of either virgin soil or bedrock, and the sequential layers were able to be horizontally and vertically connected. The vertical thickness of the cultural deposits and constructions, from the virgin soil or bedrock surface up to the top of the overlying remains, ranged from $0.5 \mathrm{~m}$ to $2.7 \mathrm{~m}$.

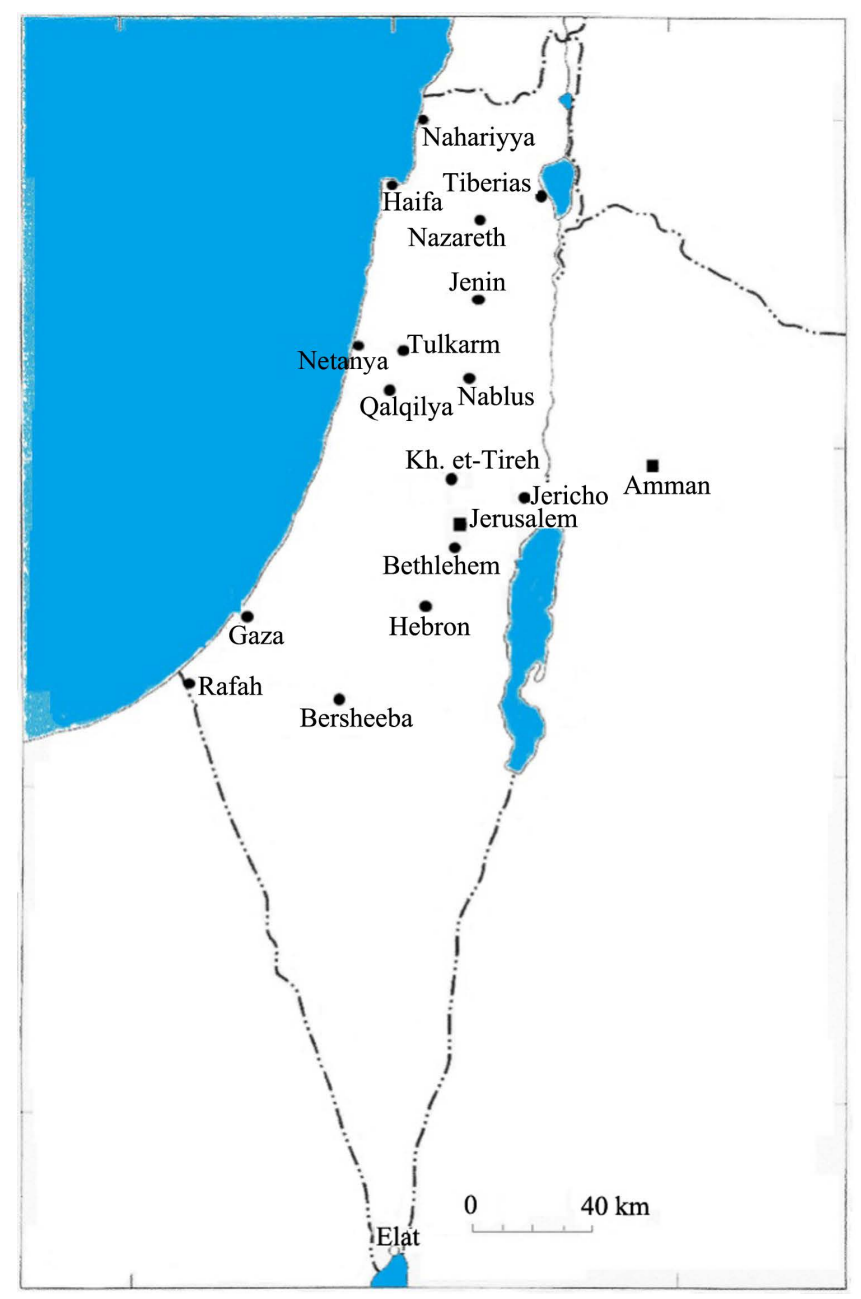

Figure 1. A map of Palestine locating Khirbet et-Tireh (drawing by I. Iqtait). 


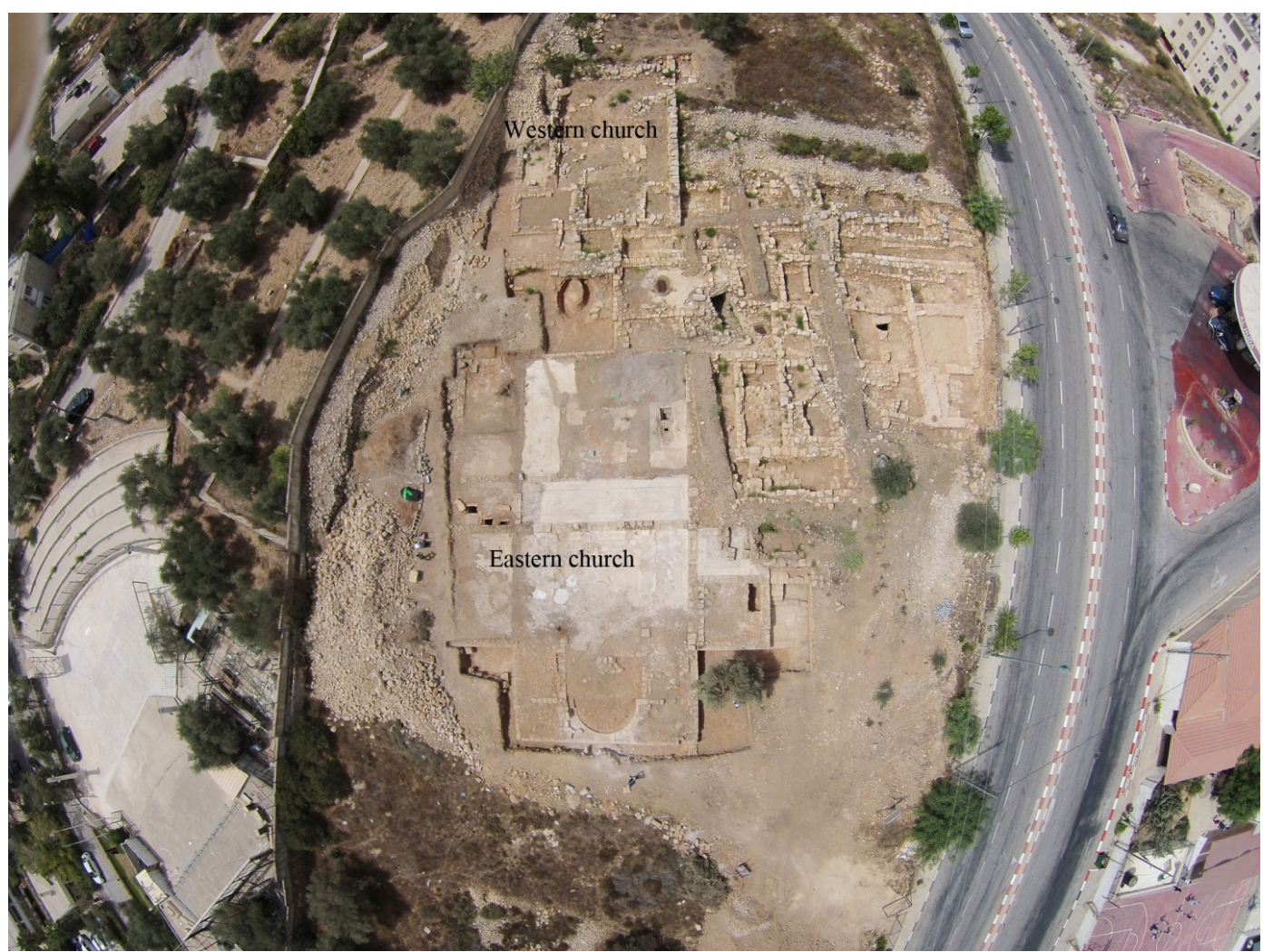

Figure 2. The areas excavated at Khirbet et-Tireh by the end of the third excavation season (photo by Khmees Al-Masri).

Two churches were excavated at the Khirbet, named by us according to their locations in relation to each other: the western and eastern churches (Figure 2). Most of the space of the western church was unearthed in the 2013 excavation campaign, however a new section of its southeastern extent was unearthed during this third campaign (2015), with a small section as yet hidden beneath a large heap of stones. This church follows a basilical plan and consists of two main parts, northern and southern. The northern part consists of a narthex and a main hall. The internal measurements of this part are $16.2 \mathrm{~m} \times 9.2 \mathrm{~m}$. The narthex measures $9.2 \mathrm{~m} \times 2.5 \mathrm{~m}$, with two doorways providing entry on its northern and southern ends. The main hall is divided by two rows of columns into a nave and two aisles. The entire area of this part of the church was once paved with mosaic carpets consisting of simple geometric designs, with the richly colored tesserae encompassing various shades of white, black, gray, orange, and pink (Al-Houdalieh, 2014). The southern part of the western church, which is only partially excavated, consists of a narrow hall connected with the church proper via two doorways. The hall's internal measurements are $2.15 \mathrm{~m}$ wide and its length might reach $12 \mathrm{~m}$. The unearthed area of this hall is paved with well-cut stone slabs of different sizes, some of them measuring $1.2 \mathrm{~m} \times 0.7 \mathrm{~m}$.

The eastern church, located $10 \mathrm{~m}$ east of the western church, is likewise situated in the southern part of the walled site, but in an area now planted with olive oil trees. Just to the south it is bounded by a poorly preserved, but massive, dry-stone terrace wall; this modern wall measures from 2 to $5 \mathrm{~m}$ in thickness and stands more than $2.5 \mathrm{~m}$ high.

\section{Research Methodology}

At the very beginning of the excavation project, a master grid-plan of $5 \times 5 \mathrm{~m}$ squares was laid out. The coordinates of these squares were designated by letters proceeding from west to east and numbers from north to south. Within each square an unexcavated margin of $0.5 \mathrm{~m}$ was left on all sides, yielding actual excavation squares of 4 $\times 4 \mathrm{~m}$ and baulks $1.0 \mathrm{~m}$ thick separating adjacent squares. The stratigraphic method used in Kh. et-Tireh relies on the baulk faces as a record of the vertical sequence of loci, thus all baulks were left standing for as long as necessary and not removed until they had fulfilled their purpose. Within each square, the loci are numbered se- 
quentially. As to the elevations, a datum point was marked at the beginning of the first excavation season on a raised stone located $2.6 \mathrm{~m}$ west of the northeastern corner of the western church $(805.65 \mathrm{~m})$. The field recording consisted of three parts: written, graphic and photographic records.

As the excavation proceeded, precautionary measures were taken to protect the plaster surfaces on the internal faces of the walls and also the floor mosaic pavements. Once the presence of such remains became clear, as a general rule we left a layer of the original soil about $10 \mathrm{~cm}$ thick in place on top of these vulnerable surfaces. This minimized the threat of any unintentional damage to the plaster layers and mosaic pavements by our team during the ongoing excavation process. Then at the end of the excavation season, after the baulks had been removed from the excavated area, the author supervised the complete uncovering and cleaning of the plasters and mosaics, assisted by three of his team who had taken part in previous conservation efforts at the site. The plasters were uncovered using trowels and then toothbrushes, while the mosaics were exposed using trowels, and then cleaned with brushes. Finally the mosaics were cleaned with water, using sponges and pieces of cloth, in order to remove residual dust from the top surfaces. The further processes of conservation, consolidation and long-term protection of these finds will be described in a separate work.

To recover any possible small finds such as seeds, beads, coins, or fragments of bones and charcoal, we sieved with 2-mm mesh screen all deposits removed directly from the floor pavements and from the crypt. Furthermore, soil samples and bits of plaster and charcoal from the different cultural layers were retained in plastic buckets or in cartons for future analysis.

Before the excavation began, an area for storing detached or tumbled building stones (both ashlars and unworked field-stones) was marked off along the southern edge of the fenced area of the Khirbet. As the excavation proceeded, all these stones were piled up without being assigned inventory numbers, due to their large numbers. The special architectural elements, however, such as drums, column bases and column fragments, were labeled with an inventory number corresponding to their excavation squares, locus and the type of element, and then stored in a specially designated spot.

\section{General Description of the Eastern Church}

The external measurements of the unearthed part of the church complex are approximately $28.5 \mathrm{~m}$ long along its east-west axis and $25.5 \mathrm{~m}$ wide in its maximum north-south dimension (including side rooms). It follows a basilical plan and its unearthed area consists of five parts: four south side rooms, an atrium; a narthex; a main hall divided by two rows of columns into a nave and two aisles; and three northeast auxiliary side rooms (Figure 3). No traces of a doorway were uncovered in the external walls of the atrium or in the southern wall of the south rooms. The only entrance to the church proper found thus far is in the southern wall of the narthex, from Room 3. So, the church might have been approached from the west through an opening in the western wall of Room 1. Even the atrium is accessed only from the narthex, through a wide doorway opening into the southern portico. The eastern wall of the narthex has three doorways which lead into the main hall. The latter is basilical in form with, as mentioned, a central nave and two side aisles; the nave terminates at its eastern end in a single inscribed (internal) apse. From the western end of the northern aisle, a doorway opens into a square room; this in turn provides access to another square room to the east and also another room on the north.

Within the excavated area of the church, traces of eight doorways were excavated (Figure 4). These doorways are quite similar to each other in their ground plan and method of construction, except for the doorway leading to Room 7. Six of the doorways are nearly identical, measuring $1.15 \mathrm{~m}$ wide and $0.6 \mathrm{~m}$ deep, however the central entrance from the narthex into the nave is considerably wider $(1.6 \mathrm{~m})$. Most of them consist of three well-cut and well-dressed pieces of hard limestone forming a sill and splayed jambs. In the corners of the recessed portion of the sills, pivot holes on either side (ca $1.5 \mathrm{~cm}$ deep and $5 \mathrm{~cm}$ wide) terminate in rounded depressions for the door hinges; rectangular slots $(6 \mathrm{~cm} \times 3.5 \mathrm{~cm} \times 1.5 \mathrm{~cm}$ deep $)$ in the center of the sill mark the positions of vertical locking bars. The smaller and anomalous doorway to Room 7 has a $0.65 \mathrm{~m}$-wide sill-stone, with only an angular recess along its outer edge and one pivot hole for a door hinge.

Most of the walls of the church were found dismantled down to the level of the mosaic pavement or even lower. Our excavations along all segments of the church's walls indicate that they were constructed immediately on top of the bedrock. The masonry of this building consists of large, sometimes well-cut and nicely dressed ashlars approximately $0.65 \mathrm{~m}$ long, $0.35 \mathrm{~m}$ thick, and $0.34 \mathrm{~m}$ high on average (Figure 5), with one section presently standing as high as $1.6 \mathrm{~m}$, at the northeastern corner. The thickness of the walls ranges between $0.6 \mathrm{~m}$ and 


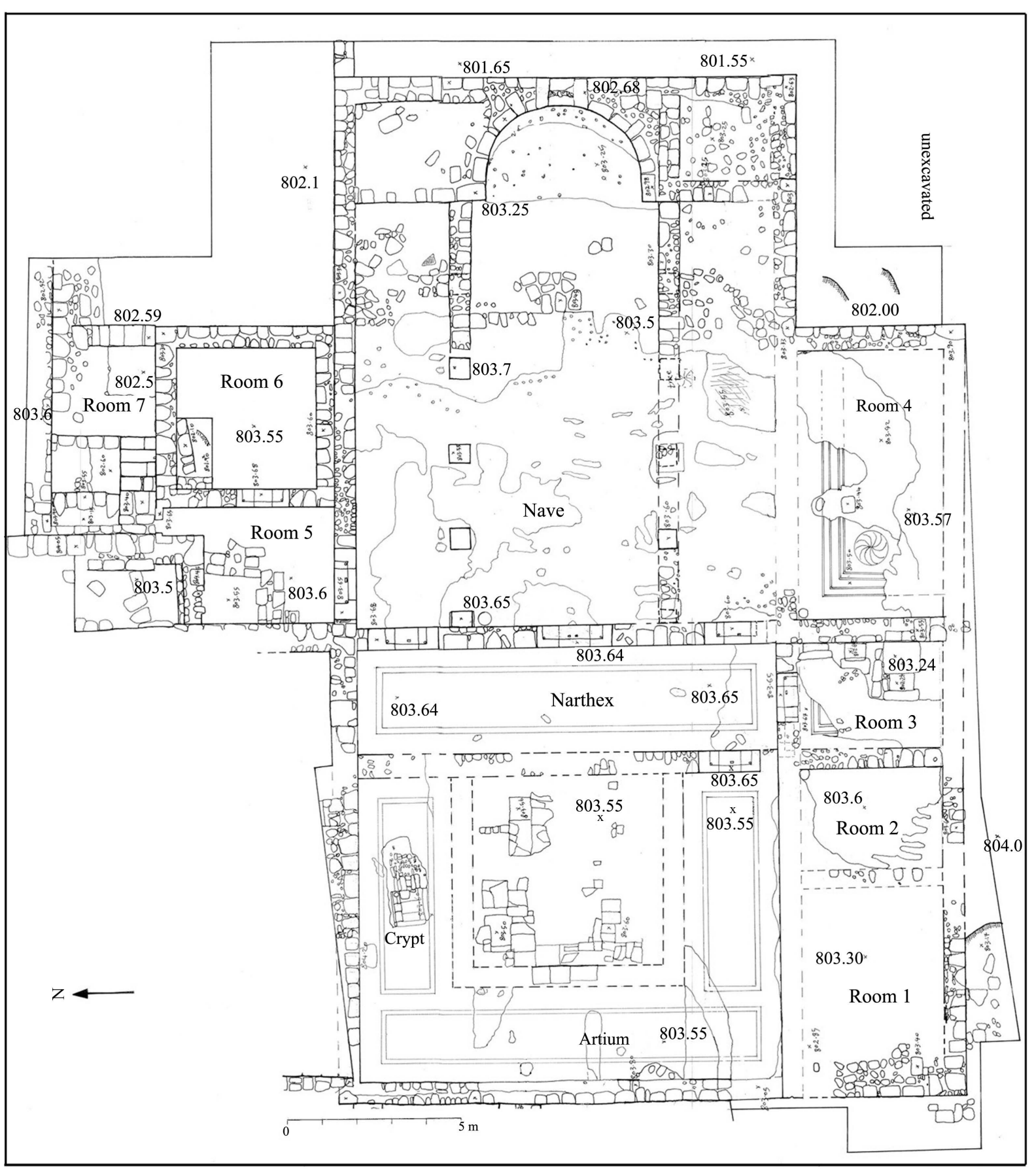

Figure 3. Top plan of the eastern church of Khirbet et-Tireh (drawing by I. Iqtait).

$0.9 \mathrm{~m}$. The outer walls of the church were built with the exterior face composed of large, dressed stones and the interior face of medium-sized stones bonded with a lime mortar mixed with brownish soil.

Enough sections of plaster were found intact to indicate that the interior faces of the walls were coated with a lime plaster applied in two coats: a base coat and a finish coat. The best preserved plaster was located on the lowest parts of the interior faces, surviving to a height of up to $20 \mathrm{~cm}$. The base layer is $2-4 \mathrm{~cm}$ thick, with a course surface, and is composed of lime mixed with a minimal proportion of ash and small natural stone aggregates. In its lower parts, this layer continues without interruption below the top surface of the adjacent floor mosaic pavement. This suggests, therefore, that the walls were first sealed with the base plaster layer and then the 


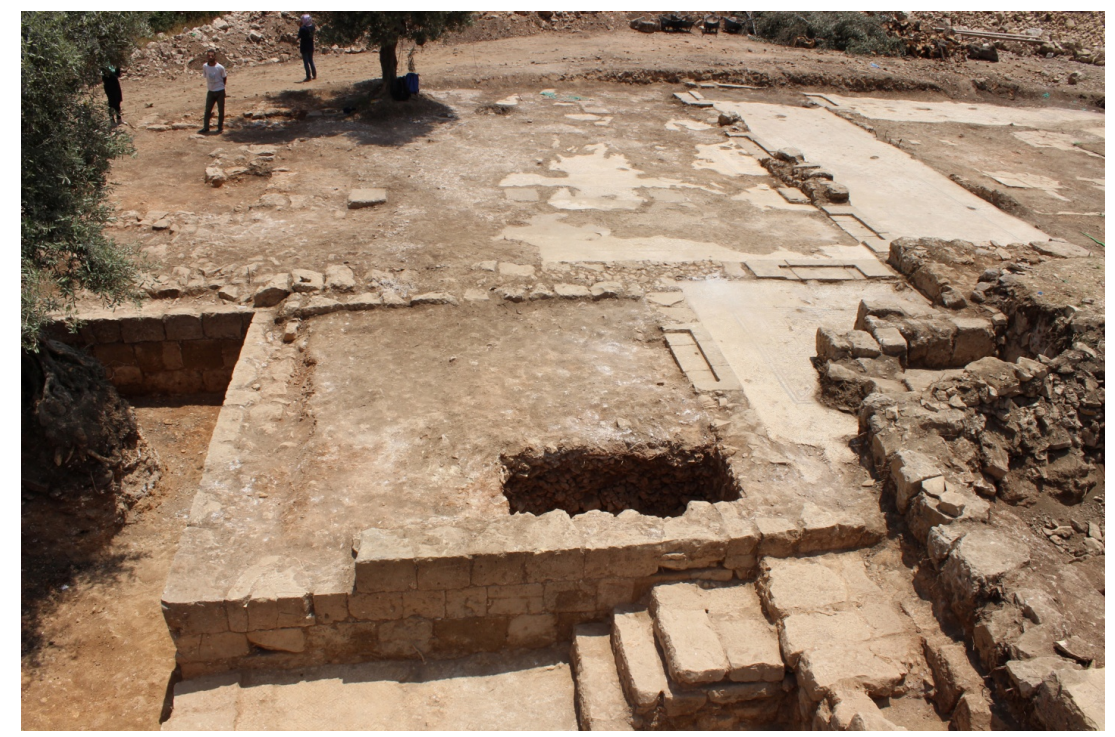

Figure 4. The doorways of the church, looking south (photo by S. Al-Houdalieh).

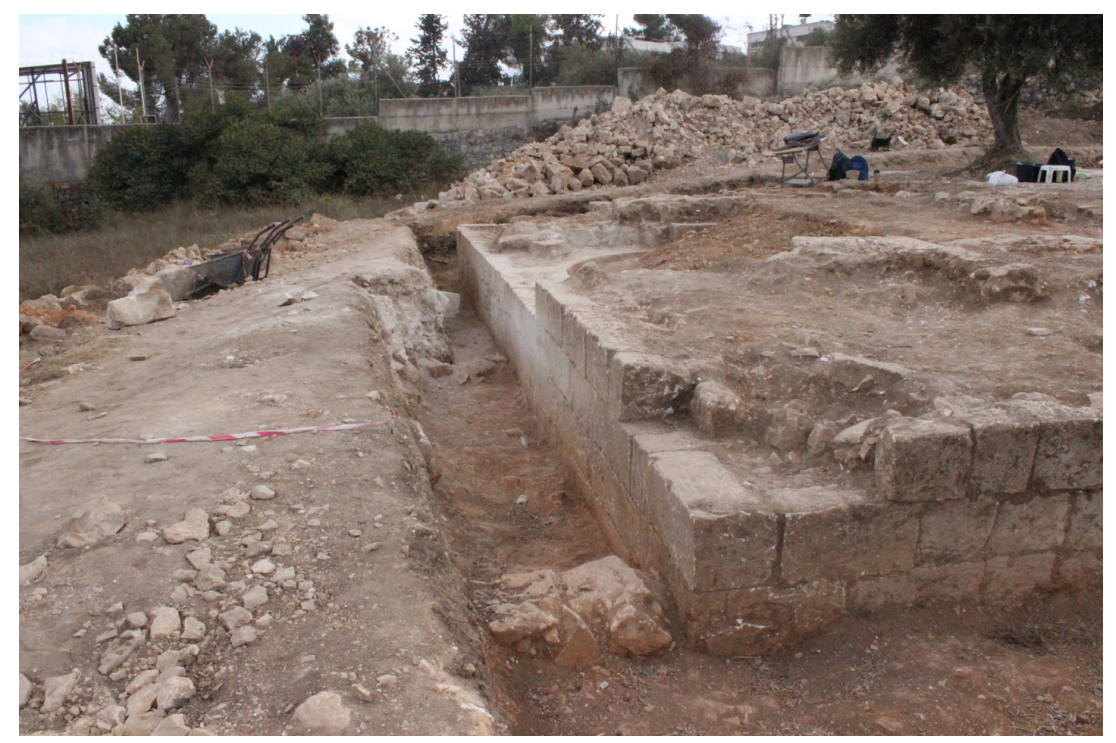

Figure 5. The masonry of the eastern walls of the eastern church of Khirbet et-Tireh, looking south (photo by S. Al-Houdalieh).

floor constructed sometime later. The younger, surface plaster layer measures 1 - $2 \mathrm{~cm}$ thick, with a well-polished surface, and is composed of lime mixed with a high percentage of ash and natural and artificial aggregates. This top-most plaster layer covers a 2 - $8 \mathrm{~cm}$-wide strip along the edge of the mosaic pavement, then continues as a curved, concave seal along the floor-wall joint, finally extending upwards to fully cover the vertical surface of the older (base) wall plaster.

No traces of plaster layers were discovered on the exterior faces of the walls. However, scattered traces of architectural ornamentation were found in the destruction layer along (outside) the eastern wall of the church, consisting of column fragments and other stone elements decorated with carved crosses and geometric designs.

No traces of any liturgical furniture were found in the area of the church, reflecting the general paucity of any cultural deposits on the church's floor. This is no doubt due to the heavy vandalism of the area, intentional and otherwise, over the past centuries. Across the entire area of the main hall and parts of the atrium, on the other hand, we encountered broken tiles, a large number of metal nails, and pieces of charcoal. These finds indicate that at least parts of the church were roofed with tiles laid atop wooden beams and latticework. 


\section{The Architectural Components of the Church}

The unearthed area of the church complex consists of the following architectural components: four auxiliary rooms along the south side; an atrium; a narthex; a main hall divided by two rows of columns into a central apsed nave and two aisles; and three more side rooms to the north of the main hall.

(1) The south rooms

Four rooms, numbered 1 to 4 from west to east, are built along (external to) the southern wall of the atrium, narthex, and the south aisle. Since the walls of these rooms had been dismantled to the level of the mosaic pavement or even lower, the means of access to these rooms are not clear. If the sole entrance to the entire building is found in the western wall of Room 1, as suggested above, we believe that Room 2 was only accessed via Room 1, Room 3 via Room 2, Room 4 via Room 3. Seemingly, the rest of the compound could only be accessed from Room 3 via the narthex. The internal measurements of these four rooms are as follows (the fixed north-south dimension is stated first): Room 1 is $4 \mathrm{~m} \times 5.2 \mathrm{~m}$, Room 2 is $4 \mathrm{~m} \times 2.8 \mathrm{~m}$, Room 3 is $4 \mathrm{~m} \times 3 \mathrm{~m}$, and Room 4 is $4 \mathrm{~m} \times 7.7 \mathrm{~m}$.

In Room 3, since the eastern part of the mosaic floor and its substrate are totally destroyed, we discovered here three parallel ground graves (Figure 6). They are oriented east-west, extending on the west beneath the intact section of mosaic pavement. The graves are all of the same length $(2.2 \mathrm{~m})$ and width $(0.75 \mathrm{~m})$; they are most likely of the same depth as well $(1.2 \mathrm{~m})$, although only one grave was cleared down to its floor. These graves were found entirely covered with large, unshaped limestone slabs, and the empty space beneath these coverslabs down to the earthen deposits in the three discovered graves was $0.8 \mathrm{~m}$ on average (Figure 7 and Figure 8).

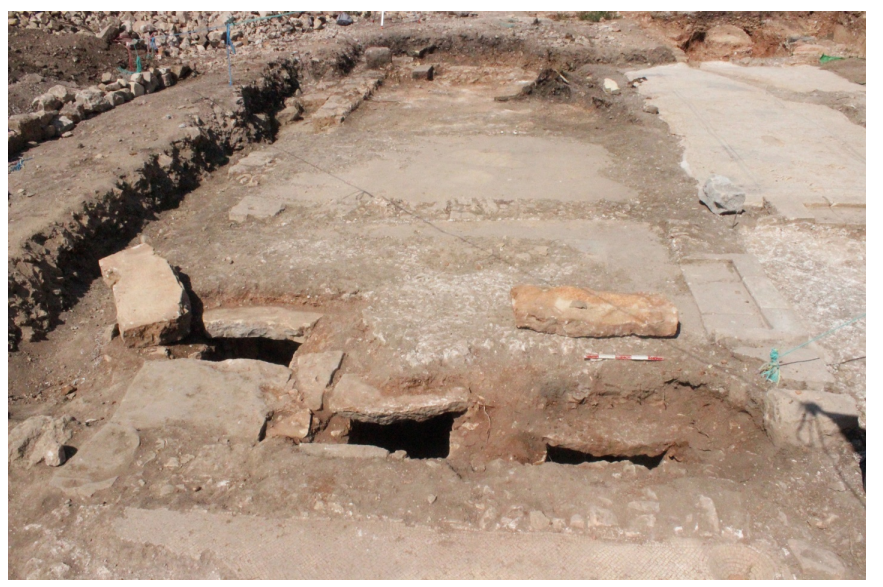

Figure 6. Three ground graves found in Room 3, looking west (photo by S. Al-Houdalieh).

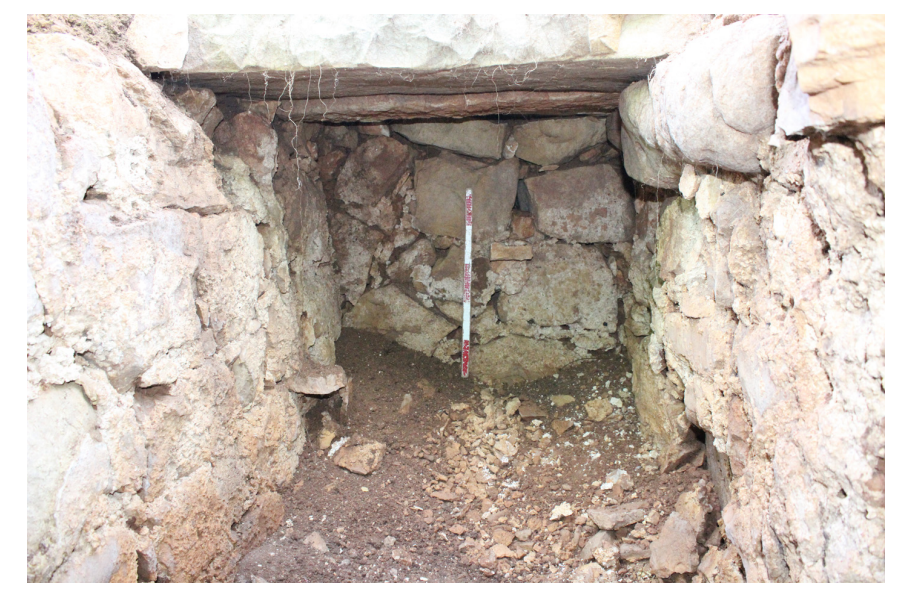

Figure 7. Ground grave 1 (the southern) before excavation, looking west (photo by S. Al-Houdalieh). 


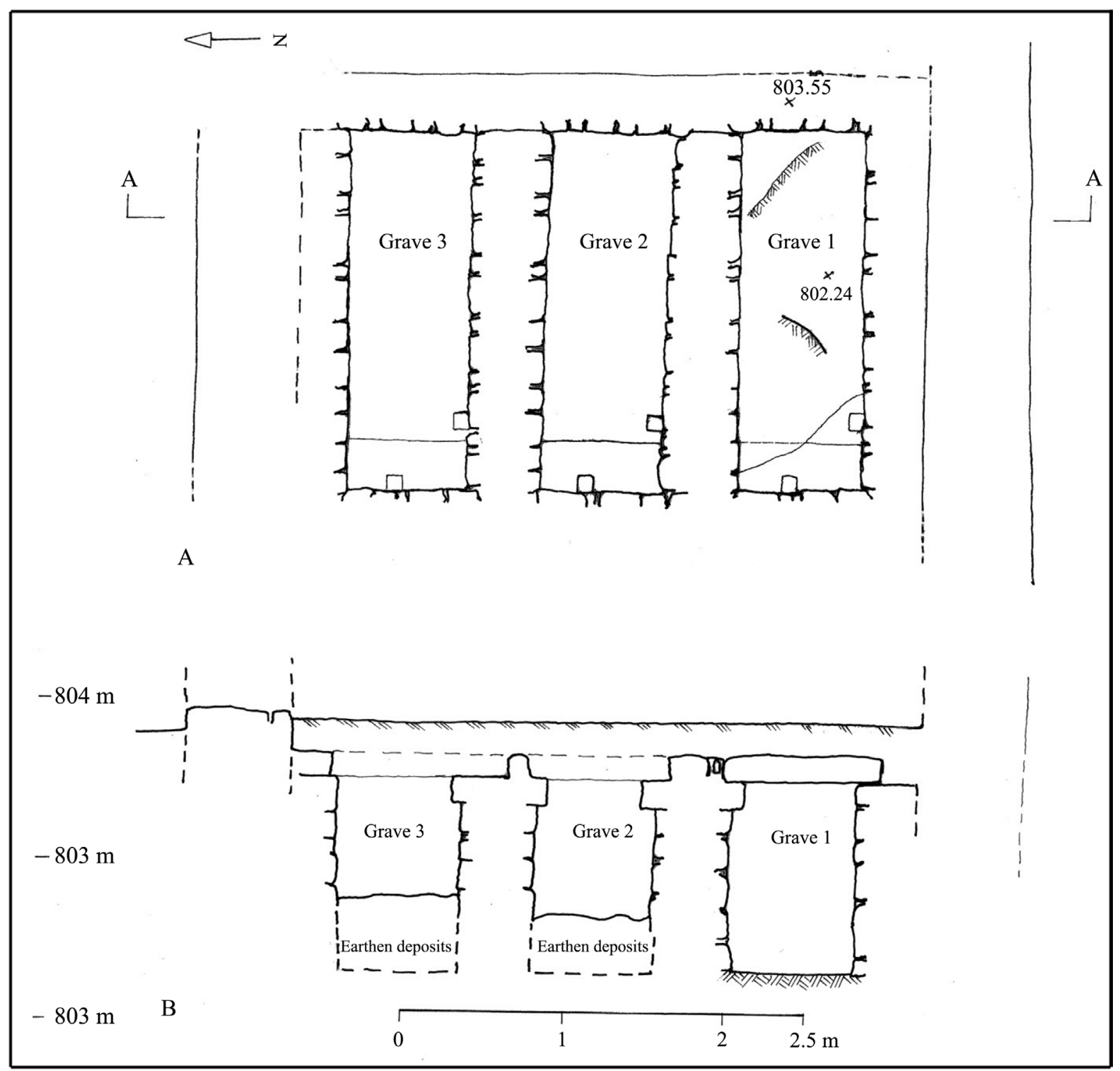

Figure 8. Three ground graves in Room 3, A: Top plan and B: Cross-section A-A (drawing by I. Iqtait).

The grave walls were built of medium-sized and large, roughly worked limestone blocks; they also have projecting stones near their southwest corners to serve as footholds. Remains of two plaster layers were uncovered, either in situ on the walls of these tombs or irregularly mixed with the upper surface of the earthen deposits accumulated inside them. The first (older) plaster layer is course, consisting of lime applied over small, thin stones to a thickness of $5 \mathrm{~cm}$ on average. The second (newer) layer measures $1 \mathrm{~cm}$ thick on average and has a polished surface. Due to time constraints toward the end of the excavation season, we fully excavated only one of these three tombs, the southern one. The floor surface of this grave was found covered with a yellowish-brown earthen deposit, $0.35 \mathrm{~m}$ thick on average, of the same characteristics as a leveling layer found above, between the covering slabs of the graves and the overlying stone substrate of the mosaic pavement. Therefore, we believe that the deposits in all three graves, being of the same composition and color, infiltrated the graves through the small spaces between the covering slabs during the preparation of the room for tessellating. No artifacts or bones of any kind were found in this one fully excavated grave. We believe that this grave, and probably the other two found in the same room, were constructed at the same time as the adjacent church, to serve as memorials for three different persons. 
(2) The atrium

The atrium occupies the northwestern section of the church compound. Its internal measurements are $12 \mathrm{~m}$ north-south and $8.5 \mathrm{~m}$ east-west. Porticoes $2.7 \mathrm{~m}$ in width form a $\mathrm{U}$ shape along its northern, southern and western sides, enclosing an open, square courtyard of $5.5 \mathrm{~m} \times 5.5 \mathrm{~m}$ fronting the narthex. Traces of three perpendicular walls were uncovered in the center of the atrium (the interior of the courtyard), with the western wall the best preserved among them. This wall survives as a single course of large, well-trimmed stones $0.5 \mathrm{~m} \times 0.5 \mathrm{~m}$ in size preserved to a height of $0.1 \mathrm{~m}$ above the level of the floor pavement.

The floor of the three porticoes is paved with colored mosaics, while the floor of the courtyard space is paved with square and rectangular slabs of hard limestone and marble. Of this stone slab pavement, only a few remains were uncovered in situ (Figure 3). It was composed of different sized, well-cut slabs, 3 to $8 \mathrm{~cm}$ thick with polished top surfaces. They are carefully laid close together on a bedding layer on top of a statumen consisting of small stones and lime mortar. The spaces between the slabs are filled with a brownish mortar mixed with lime. The majority of these slabs show cracks of different sizes and directions; it is believed they were broken by fallen stones in the destruction of the building.

The atrium shares its northern wall with a rectangular room, however the floor level of the atrium is approximately $0.3 \mathrm{~m}$ higher than that of this adjacent room. Also, since the northwestern corner of the atrium extends beyond the line of the western wall of the neighboring rectangular room, which forms part of a large building, we believe that the atrium was built first, then this rectangular room was added later. The north wall of the atrium is $9.7 \mathrm{~m}$ long and was found to extend $0.3 \mathrm{~m}$ below the floor surface. Its external face was not fully exposed due to the presence of the main baulk (1.5 m wide) intentionally left as a pathway for the use of visitors, for access to the olive oil press and other exposed structures within the excavated areas. The atrium's other three walls, on the other hand, were found mostly destroyed to below the level of the mosaic pavement.

A channel, mostly intact, leads from the northwestern corner of the atrium to a rectangular cistern opening lying ca. $6 \mathrm{~m}$ to the northwest. This uncovered (northern) part of the channel traverses an open space and has been traced for a distance of $6.5 \mathrm{~m}$ (Figure 9), while a southern extension (not excavated completely) runs beneath the mosaic pavement just inside the western wall of the atrium. The northern part of this channel measures $0.15 \mathrm{~m}$ wide and $0.15 \mathrm{~m}$ deep in cross-section, its sides and floor constructed of small stones covered with plaster; the floor gradient descends toward the northwest. The plaster layer consists of lime, ash, grog and small natural aggregates, with a thickness ranging between $8 \mathrm{~mm}$ and $5 \mathrm{~cm}$. The channel is covered by stone slabs sealed with lime mortar in between. These slabs covering the northern, excavated part of the channel were laid side-byside along the western exterior wall of an elongated room (mentioned above), as was the practice during the second phase of the Byzantine period. This would seem to indicate that the channel was constructed after the adjacent room. It is believed that the channel was connected to vertical drain pipes located in the western corners of the atrium and thus used to collect rainwater from the roofs of the building, as well as from the surface of the atrium's courtyard.

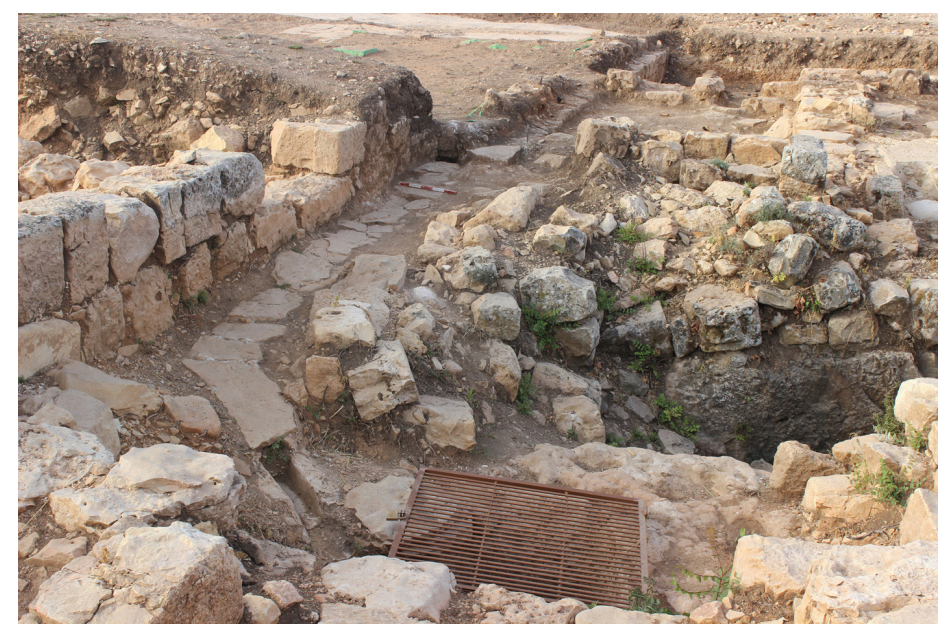

Figure 9. The water channel at Khirbet et-Tireh, looking south (photo by S. Al-Houdalieh). 
A crypt was unearthed in the northern portico of the atrium, consisting of a vertical and then a lateral opening, leading down to a subterranean chamber (Figure 10). The well-constructed, squarish vertical opening measures $0.85 \mathrm{~m} \times 0.9 \mathrm{~m} \times 1.1 \mathrm{~m}$ deep, and its northern, southern and western edges are built of well-cut and dressed stone slabs, with their top edges protruding $1 \mathrm{~cm}$ above the level of the mosaic pavement. Going down, this opening is narrowed by shallow ledges installed on either side of a short staircase consisting of two steps descending to the crypt. The two ledges measure $0.85 \mathrm{~m}$ long and $0.16 \mathrm{~m}$ wide, built of dressed, medium-sized stones, with their top surfaces $0.35 \mathrm{~m}$ below the level of the mosaics. The uppermost step is built of dressed, medium-sized stones, while the lower one is cut into the bedrock. It is believed that the two ledges were used to support the edges of stone slabs (or perhaps one large slab) that covered the opening in antiquity. Descending through the opening, the below-floor space opens eastward through another doorway, which is intact and well-preserved, with internal dimensions (in cross-section) of $0.8 \mathrm{~m}$ high $\times 0.5 \mathrm{~m}$ wide.

The subterranean chamber itself measures $2.2 \mathrm{~m} \times 2 \mathrm{~m} \times 1.55 \mathrm{~m}$ high and includes three east-west oriented ground graves separated from each other by upright stone slabs $0.15 \mathrm{~m}$ in width (Figure 11). The northern and southern graves are similar in shape and size ( $2 \mathrm{~m}$ long $\mathrm{x} 0.66 \mathrm{~m}$ wide $\times 0.4 \mathrm{~m}$ deep), while the middle one is smaller $(1.5 \mathrm{~m}$ long $\times 0.55 \mathrm{~m}$ wide $\times 0.4 \mathrm{~m}$ deep). The walls of this chamber are constructed of medium-sized, unshaped stones $0.25 \mathrm{~m}$ long and $0.2 \mathrm{~m}$ wide, while the vaulted ceiling is fashioned from smaller stones $(0.2 \mathrm{~m}$ $\times 0.1 \mathrm{~m}$ on average) laid carefully edge-to-edge and bonded with a lime mortar; the chamber's ceiling construction served also as the stone substrate of the mosaic pavement directly above. Remains of two plaster layers were uncovered on the walls of the crypt: a base coat and a finish coat. The base layer, 3 to $6 \mathrm{~cm}$ thick, was applied so as to render the surface of the walls quite even; where there was sufficient thickness, small thin stones and pottery sherds had been pressed into the mortar while it was wet. The finish coat is $1 \mathrm{~cm}$ thick, on average, and has a polished surface. Both layers consist of lime, grog, and small aggregations.

The crypt chamber was found filled to the ceiling with grayish earthen deposits mixed with a large number of stones of different sizes, including well-cut large stones, and with many fragments of plaster layers at different levels, all of which might indicate that the earthen deposits infiltrated the chamber through its doorway over a long period of time. Furthermore, four fragments of covering slabs made of heavy white marble, probably once covering the crypt entrance above, were recovered from the middle grave; one fragment showed traces of lime mortar on one of its flat sides. The disturbed skeletal remains of three individuals were retrieved from the southern ground grave; in addition, a few teeth, ribs, femurs, a mandible, tarsal bones, metacarpals and other fragmentary bones were recovered from the other two graves. The disturbed bones of the three graves were associated with one nearly complete oil lamp and fragments of other lamps (Figure 12), pottery sherds of a jar, five glass beads, and a few glass sherds of a bottle and some cups. The field study of the bones indicates that the three skulls and a large number of the long bones were broken very long ago.

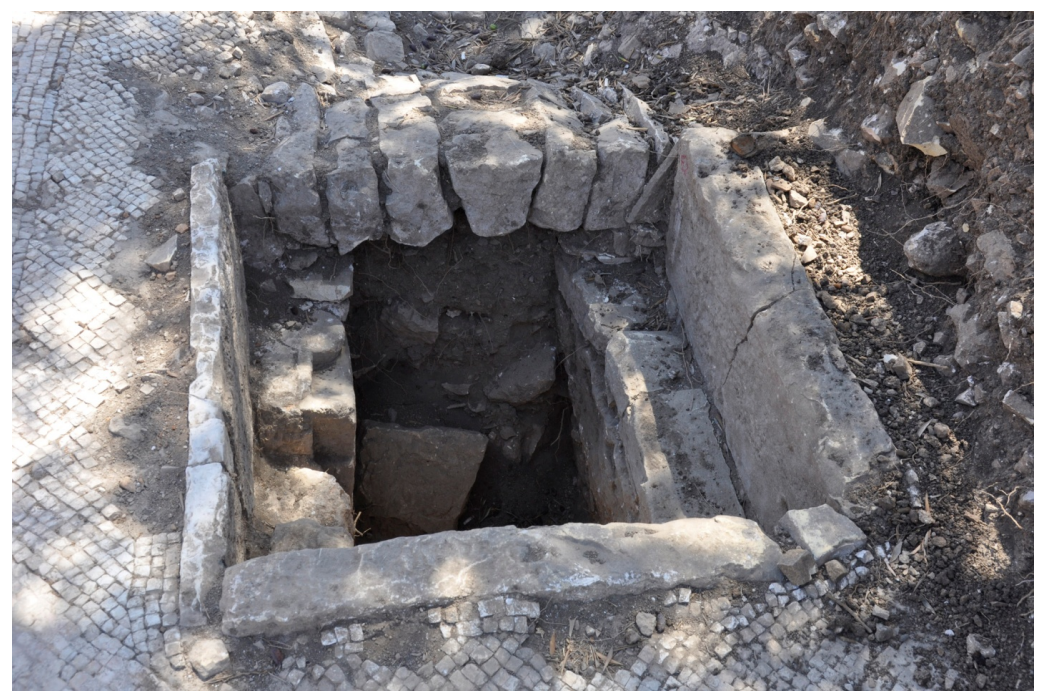

Figure 10. The vertical and the lateral openings of the crypt, looking east (photo by S. Al-Houdalieh). 


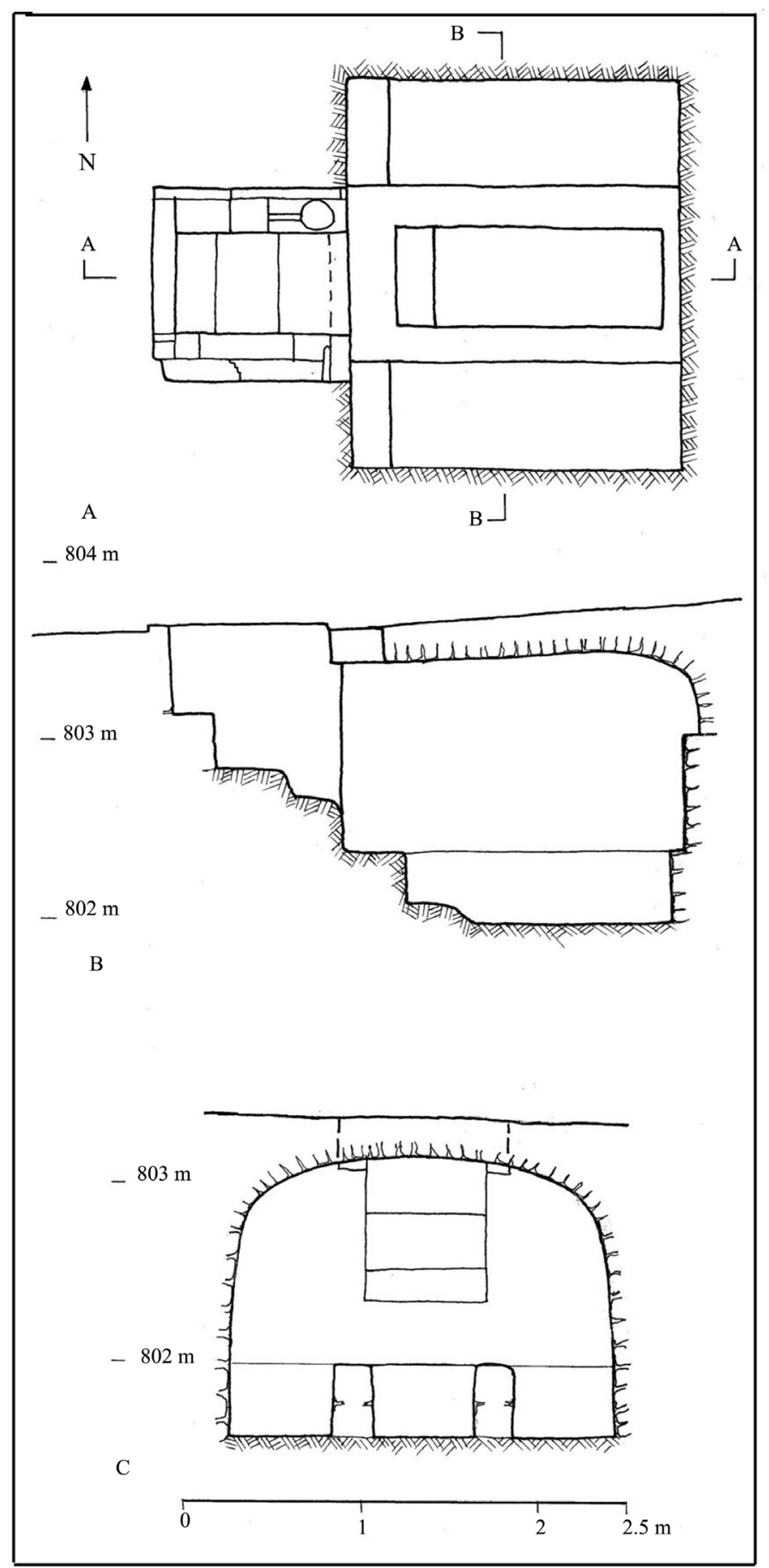

Figure 11. The crypt, A: Top plan; B: Cross-section A-A; C: Cross-section B-B (drawn by I. Iqtait).

The human skeletal remains recovered from each of the graves were collected separately in boxes, stored for a few days in the site storeroom, then (at the request of the Patriarchate) gathered in a single coffin together with their documentation tags. The remains were transported on 4 August 2015 in a solemn funeral procession to the Greek Orthodox Church in Ramallah, where a requiem was celebrated. This unique historical and religious event was organized under the auspices of the Greek Orthodox Patriarchate and attended by the patriarch, a large number of clergy, the author, representatives of Al-Quds University, the Governor of Ramallah Governo- 


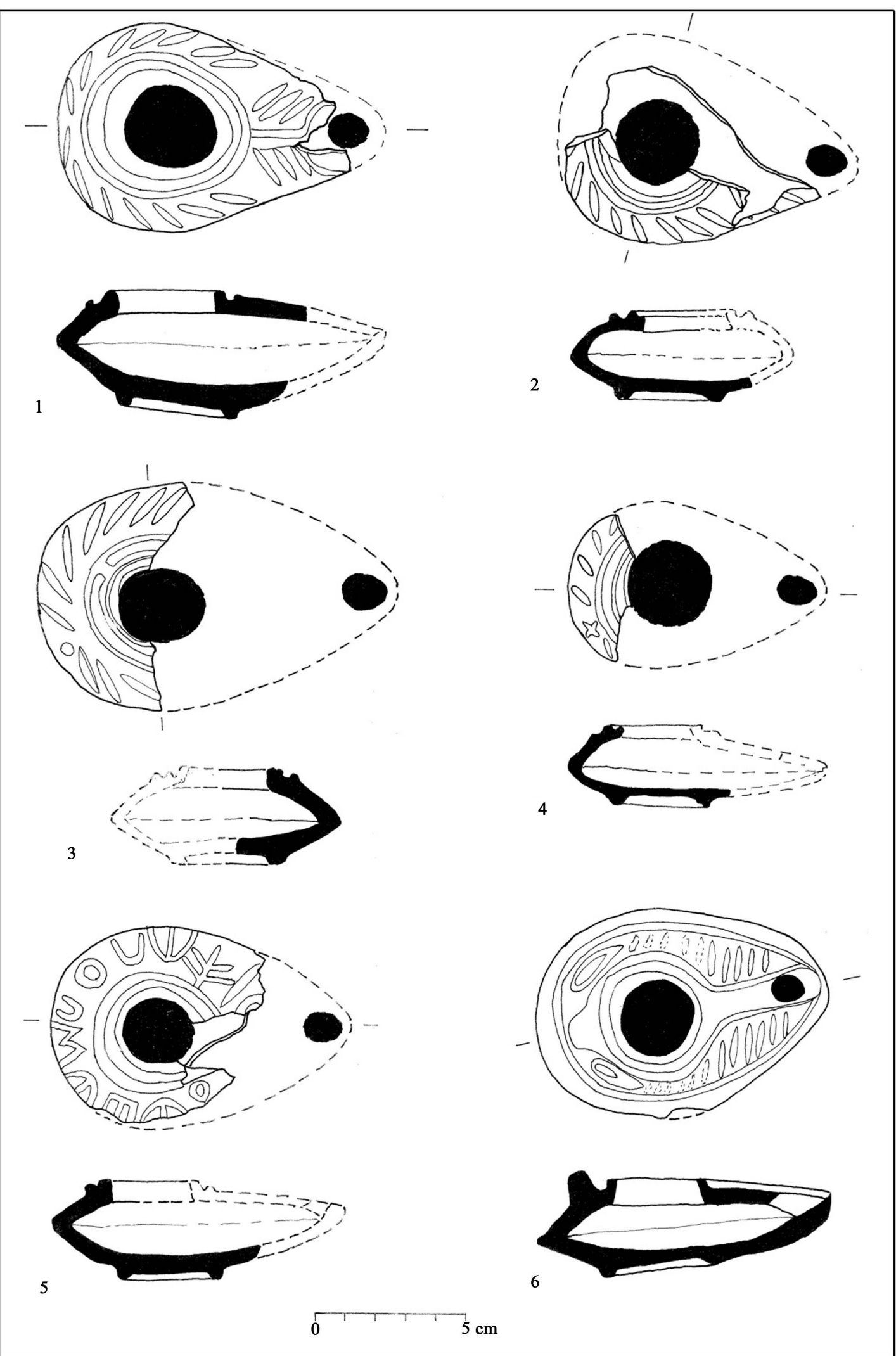

Figure 12. Oil lamps found in the crypt (drawing by I. Iqtait). 
rate, the administration of Ramallah Municipality, notables of Ramallah and Jerusalem, and a large number of Ramallah's lay Christian community. This distinguished event was covered by national and international media agencies.

(3) The narthex and the main hall

The narthex measures $11.85 \mathrm{~m}$ by $3 \mathrm{~m}$, and three entrances in the east wall connect the narthex with the main hall: a large central doorway opens into the nave, and smaller doorways on either side open into the aisles (Figure 3). The main hall is divided by two rows of columns into a nave and two aisles. The measurements of the nave are $14.5 \mathrm{~m}$ long by $5.35 \mathrm{~m}$ wide. Each of the aisles is about half as wide as the nave. Four plinths of the northern row and one plinth of the southern row were found in situ, while the remainder had been removed or destroyed completely. Each plinth consists of a single large well-cut and dressed stone of $0.6 \mathrm{~m}$ by $0.6 \mathrm{~m}$. The top surfaces of the uncovered plinths stand a few centimeters higher than the level of the floor pavement (although their complete vertical height was not explored). Based on the regular distance between the intact plinths of the northern row and on the total length of the nave, we believe that the two rows consisted of six columns each. The top surfaces of two east-west oriented walls were also traced on either side of the nave, on the hall's eastern and western ends, where the mosaic pavement and its substrate were found completely destroyed. These walls were built of different sized stones to $0.6 \mathrm{~m}$ in thickness and run exactly in line with the rows of the columns. Thus, we believe that the two walls run immediately beneath the plinths and were built to create a solid foundation (stylobate) for the rows of columns. Related to this, we noted that the adjacent fill deposits below the level of the floor pavement measured up to $1.7 \mathrm{~m}$ in thickness (down to bedrock). Finally, traces of two short north-south oriented walls built of different sized stones and measuring $0.6 \mathrm{~m}$ thick were uncovered on either side of the apse. Since these walls were destroyed to below the floor level, no evidence of doorways passing through them was identified. However, we believe that the apse was flanked by two small side chambers of equal dimensions, $2.4 \mathrm{~m}$ by $2.8 \mathrm{~m}$.

(4) The three north side rooms

From the church's north aisle a doorway opens into Room 5, which in turn provides access to two other rooms (Figure 3), one to the east (Room 6) and the other to the north (Room 7). The internal measurements of Room 5 are $2.8 \mathrm{~m} \times 2.3 \mathrm{~m}$, plus a short corridor $1.2 \mathrm{~m}$ long and $0.7 \mathrm{~m}$ wide in its northeastern corner. Traces of two perpendicular partition walls were unearthed in the northwestern part of this room. They are roughly built of large and medium-sized stones, immediately on top of the mosaic pavement. These two later walls, together with parts of the original western and northern walls of the larger room, enclose a small square space only 3 square meters in area. Based on archaeological evidence, it is believed that the partitioning of this room occurred after the destruction of the church, to create a living space for a survivor of the earthquake.

Room 5 opens to Room 6 through a doorway located in the middle of their common wall. The internal measurements of this room are $4 \mathrm{~m} \times 4 \mathrm{~m}$. Our explorations revealed that the original south wall of Room 6 was the same as the northern wall of the church's main hall. Sometime later, a plaster layer was added to the northern face of this shared wall. Then, on top of the plaster coat, a partial, low wall $0.5 \mathrm{~m}$ thick was built against the original wall, as an addition to the interior of Room 6. Of this new (partial) south wall, what appears to be its topmost course stands only $10 \mathrm{~cm}$ higher than the adjacent mosaic bedding layer; the same wall also continues downward, below the level of the bedding. Thus the low wall, which perhaps originally served as a bench, clearly predates the room's mosaic installation. Incidentally, none of the mosaic itself survived, in the entire room. A trial trench $2 \mathrm{~m}$ long and $1 \mathrm{~m}$ wide was excavated in the northwestern corner of this room. The results of that sounding suggest the following: (1) the northern and western walls of this room were built on a broad foundation laid immediately on top of the bedrock; (2) The vertical distance between the bedrock surface and the stone substrate of the mosaic bedding layer was backfilled with a layer (1.7 m thick) of yellowish-brown earth mixed with a large number of small- and medium-sized stones, along with a small quantity of pottery sherds dated to the Roman and Early Byzantine periods; and finally, (3) traces of a single plaster layer were identified only on the interior face of the western wall of this room, beginning at the interface of the filling layer and the stone substrate and extending upward. The bottom edge of this plaster layer is quite straight and thick, which means that it was applied after the filling layer was laid down but before the construction of the mosaics.

Room 5 also opens to Room 7, through a corridor and doorway located in its northeastern corner. The internal measurements of the Room 7 are $4 \mathrm{~m} \times 2.9 \mathrm{~m}$, and its floor level is $1.1 \mathrm{~m}$ below that of the rest of the church complex. A staircase built directly on the plain white mosaic pavement was unearthed in the southwestern corner of this room (Figure 13). It is constructed of large, roughly-cut pieces of limestone and consists of two steps 


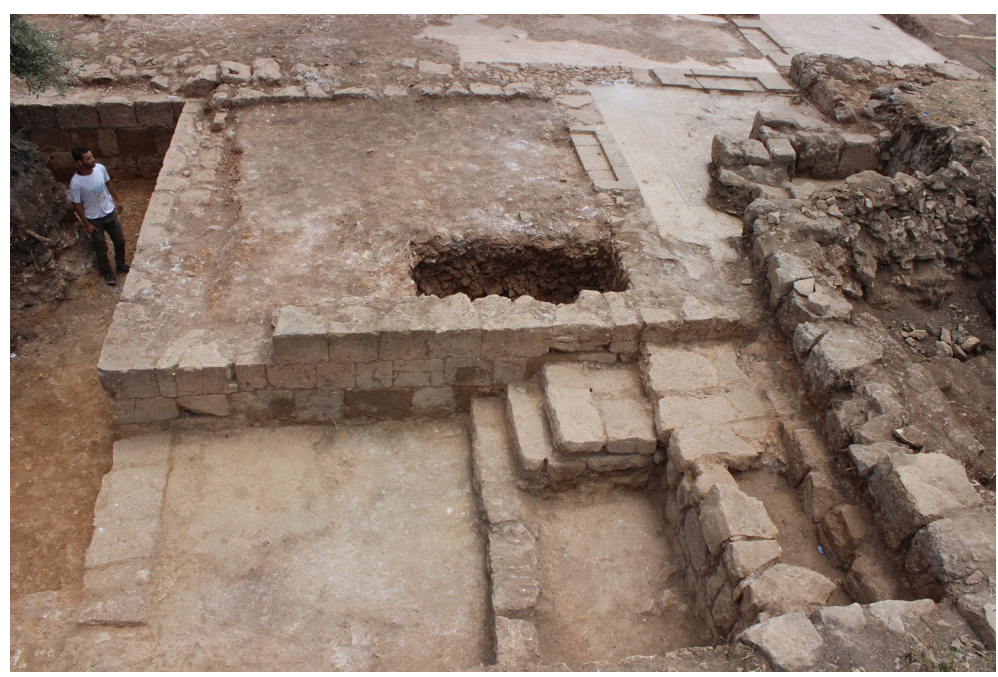

Figure 13. The staircase in room 7, looking south (Photo by S. Al-Houdalieh).

and two landings leading up to a the above-mentioned doorway connecting with Room 5. The topmost landing is actually part of a platform built of large pieces of limestone and running the length of the room's western wall. The rest of the staircase is $0.95 \mathrm{~m}$ wide and all the risers are $0.22 \mathrm{~m}$ in height; the two steps measure $0.3 \mathrm{~m}$ in depth and the landing (and platform) between $0.9 \mathrm{~m}$ and $1.15 \mathrm{~m}$. The presence of a platform just at the top of this staircase might indicate a further stairway once leading to the roof or to a second story above Rooms 5 and 6 . The walls of this room are still standing to a height of $1.1 \mathrm{~m}$ on average, except its eastern wall which was dismantled down to the floor level. Thus, there is no actual evidence of an opening in the east wall of the room. Nevertheless, since the level of the remains of a stone pavement in the adjacent area to the east matches the level of the mosaic pavement of Room 7, a doorway in the east wall would be expected.

The general layout of this church resembles others found in Palestine, such as at: Kursi (Tzaferis, 1993: p. 77-79), Khirbet el-Beiyudat (Hizmi, 1990), Ruheibeh (Figueras, 1995: p. 435), Magen (Margalit, 1995: p. 392395), Khirbet al-Karak (Haines, 1960: p. 6-20, pl. 13), Beit Loya (Patrich \& Tsafrir, 1993: p. 266), Haluza (Negev, 1993), Rehovot-ba-Negev (Korzhenkov \& Mazor, 2014: p. 78), and Ostrakine (Oren, 1993).

\section{The Mosaics of the Church}

The floor pavement of the church complex consists of colored mosaics, except in Room 7 where it is composed of simple white cubes ( $2.3 \mathrm{~cm}$ thick on average, at a density of 16 tesserae per 100 square centimeters). The best preserved mosaic pavements are located in the atrium, the narthex, and in Room 5, while the others were either partially or totally destroyed. An outer margin of white tesserae runs along the interior faces of all walls of the church complex where colored mosaics were found. According to the laying pattern of the mosaic, these plain margins consist of two parts: (1) first, a narrow outer band consisting of three rows of tesserae, ranging between $4 \mathrm{~cm}$ and $6 \mathrm{~cm}$ in total width and laid at right angles to the wall; (2) a much wider inner band, ranging between $45 \mathrm{~cm}$ and $65 \mathrm{~cm}$ in width, laid at a 45-degree angle relative to the walls (and to the frame of the carpets).

Six mosaic carpets, varying in size and physical condition but identical in their decorative patterns, were revealed in Room 2, Room 3, the atrium and the narthex. The carpets in the atrium and narthex range between $5 \mathrm{~m}$ and $10.7 \mathrm{~m}$ long and between $1.5 \mathrm{~m}$ and $1.9 \mathrm{~m}$ wide, while they are smaller in Rooms 2 and $3(3.2 \mathrm{~m} \times 2 \mathrm{~m}$ on average). These mosaic carpets are framed by simple lines formed of black tesserae, a double row on the outside and a single row on the inside, with two rows of white tesserae in between. The ornamentation of the interior of the carpet consists of a homogeneous repeating petal design rendered in black and orange on a white background. It is worth noting that the mosaic pavements of the atrium, Room 2, Room 3, and the narthex are all similar-in overall construction and the size, color and shaping technique of the tesserae- to those found in the western church unearthed nearby on the same site. These pavements all consist of medium-sized tesserae $1.5 \mathrm{~cm}$ by 1.5 $\mathrm{cm}$ and $2.1 \mathrm{~cm}$ thick on average, at a density of 35 tesserae per 100 square centimeters. The cutting and setting techniques of the tesserae are of high quality, with good cubical shaping and well-polished upper surfaces. 
The mosaic pavement of Room 4 is quite well preserved on its northwest corner, however over the rest of the room it was completely destroyed, together with its stone substrate. The tesserae of this room are of approximately the same size as those found in Rooms 2 and 3. They are laid in rich geometric patterns rendered in black, grey, orange and yellow on a white background. The top surface of this mosaic pavement includes several uneven depressions caused by the impact of fallen stones. Furthermore, it includes in its northwest corner a bowl-shaped depression, $0.27 \mathrm{~m}$ in diameter and $0.11 \mathrm{~m}$ deep, which may have been used for collecting water that drained off the floor during cleaning.

The mosaic pavement of the main hall is preserved only on the western end, being completely destroyed over the rest of the hall. The tesserae of the main hall are smaller than those in the atrium and the narthex (150 cubes on average per 100 square centimeters) and laid in geometric and figurative patterns of black, grey, yellow, orange, pink, wine red, green and blue, all on a white background. Parts of several mosaic carpets, varying in size, physical condition and decorative pattern, were revealed in this pavement. The pavement of the nave was planned as a single framed unit, but was divided geometrically into panels. It consists of two rows of small panels on the western end, one row of small panels on both the northern and southern sides, and of large carpets in the central areas. Each small panel is framed by a single line of black tesserae and measures $0.28 \mathrm{~m}$ square on average; the panels, which feature geometric or figurative patterns, are separated from each other by 0.12 m-wide braids or crosses. All of the figurative ornamentation of this pavement was altered in antiquity and replaced with white tesserae (Figure 14). Based on the trace remains of the original figures, and on the shapes filled in by the alteration, we can conclude that the depictions were of human, animal, bird (Figure 15), fish and floral figures. A bowl-shaped depression $0.31 \mathrm{~m}$ in diameter and $0.2 \mathrm{~m}$ deep was found in the northwestern corner of the nave. This depression is tessellated with white cubes and might have been used to hold a jar or to collect water which drained off the floor during cleaning. The remains of the pavements of the two aisles indicate that, unlike the nave, they consisted only of geometric patterns on a white background.

The mosaic pavement of Room 5 is well preserved, and its tesserae are larger than those in the main hall but smaller than the cubes of the atrium and the narthex. They are laid (50 cubes per 100 square centimeters) in geometric patterns of black and orange on a white background. The mosaic carpet of this room measures $2.4 \mathrm{~m}$ by $2.4 \mathrm{~m}$. Outermost is a wide, diagonally-laid margin whose ornamentation consists of a repeating petal design rendered in black and orange on a white background, resembling those found in the atrium and the narthex. Next, the carpet is framed by (counting from the outside): three rows of white tesserae, two rows of black, two more rows of white, and finally two single rows of black separated by three rows of orange. The geometric pattern of the carpet itself consists of interlocking octagons each with a small square at its center; each of the resulting white spaces contains a small, cross-shaped lozenge.

The mosaic cubes of all the pavements (except in Room 7) were installed on top of six layers. From top to bottom, these are: a bedding mortar layer $1 \mathrm{~cm}$ thick, on average; a nucleus layer which is much thicker than the

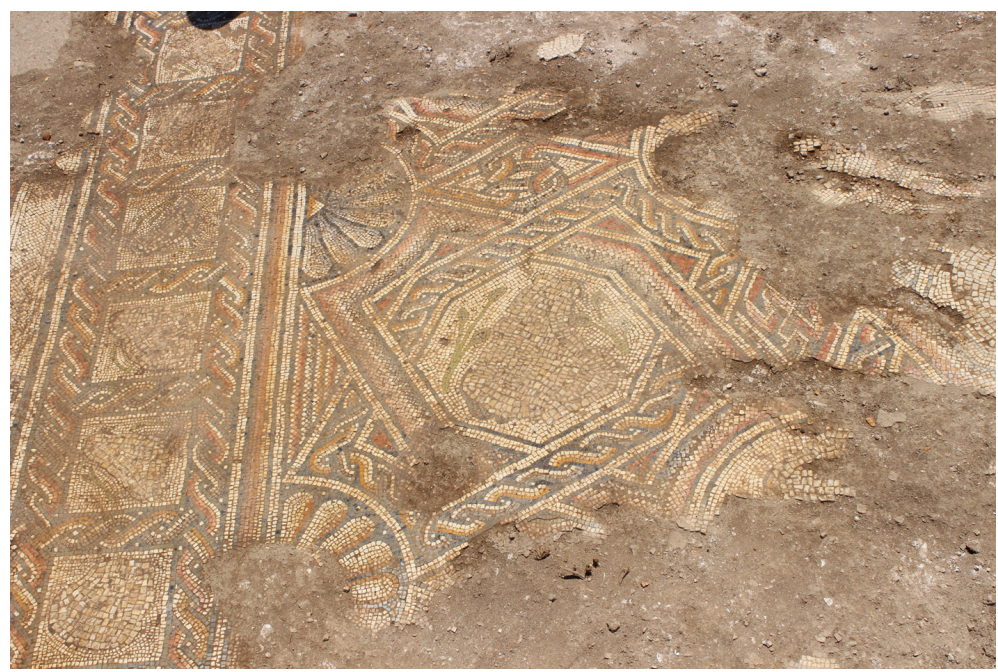

Figure 14. Mosaic pavement of the main hall (looking east), showing iconoclastic alterations (photo by S. Al-Houdalieh). 


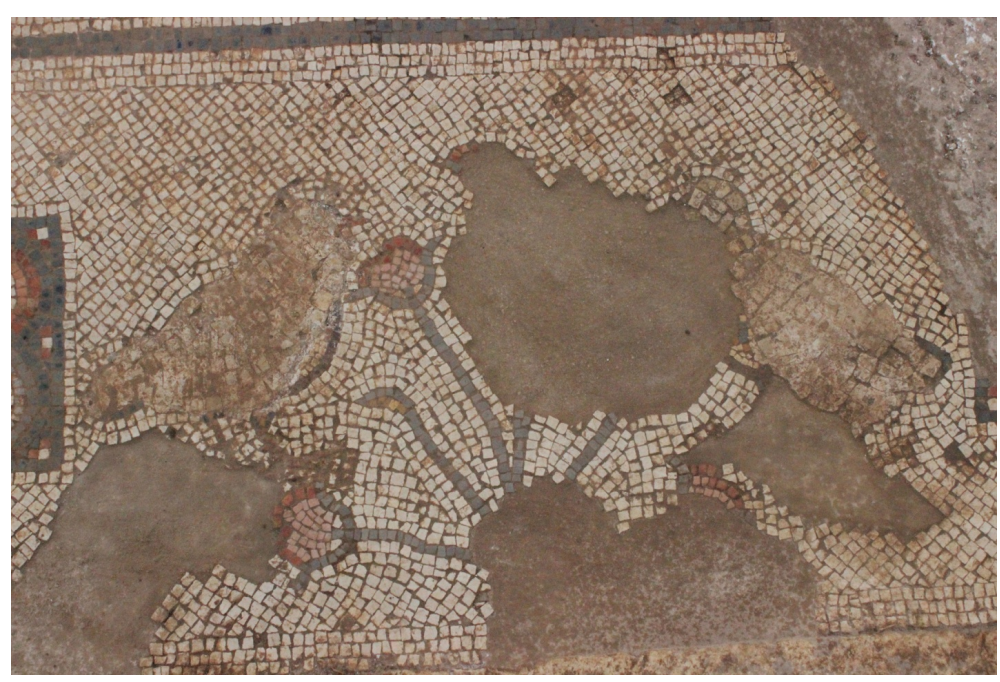

Figure 15. Alteration of two birds flanking a floral pattern (photo by S. AlHoudalieh).

overlying one ( $1.5 \mathrm{~cm}$ to $2 \mathrm{~cm}$ ); a stone pavement $7 \mathrm{~cm}$ to $12 \mathrm{~cm}$ thick; a leveling layer of earthen deposits of 10 $\mathrm{cm}$ to $15 \mathrm{~cm}$; a preparatory stone pavement $0.2 \mathrm{~m}$ to $0.3 \mathrm{~m}$ thick; and on the bottom, an earthen fill ranging from $1 \mathrm{~m}$ thickness over the western part of the church to $1.7 \mathrm{~m}$ in the eastern part, varying with the elevation of the underlying bedrock surface which slopes generally downward toward the east.

Our study of the stone types of the tesserae indicates the following: The white tesserae are limestone, believed to be obtained in the vicinity of the settlement. The black tesserae are bituminous stones which are found naturally in the el-Nabi Mousa area, about $8 \mathrm{~km}$ south of Jericho. The orange tesserae are similar to those found at a large number of archaeological sites throughout Palestine and Jordan and most likely imported from southern Jordan.

Toward the end of our second and third excavation seasons at et-Tireh, the mosaic pavements of the church (except Rooms 2, 3, 4 and 7), as well as the plaster layers on the internal walls of this complex, were conserved, consolidated and then reburied. The conservation work took place over a period of 12 weeks, carried out by a working team of seven persons. The processes and results of this conservation work will be published in a separate paper.

\section{The Destruction and Vandalism of the Church}

Based on archaeological evidence and on information provided by interviewees, we can conclude that the church and its ruins were vandalized several times, beginning in the eighth century and continuing into modern times. This vandalism can be summarized as follows:

Iconoclasm: Archaeological evidence shows that the mosaic floor pavements suffered from the impact of iconoclasm, which might have occurred during the first half of the eight century. The mosaics, especially in the nave, were altered: the colored cubes forming human figures, animals, birds or fish were picked out and replaced crudely with white tesserae of a larger size than the original cubes (Figure 14 and Figure 15). The deliberate defacing of the mosaic pavement of Khirbet et-Tireh resembles that of others in the Levant, such as: alQuwaysmah (Schick \& Suleiman, 1991: p. 325-340), Um al-Rasas and Ma’in (Ousterhout, 2001: p. 32-33), Deir al-A’das (Schick, 1995: p. 205-206), Nabha (Ousterhout, 2001: p. 33), ‘Ain al-Kanisa (Schick, 1998: p. 87).

An earthquake: Based on archaeological clues found within the destruction layers of the church and of other unearthed architectural units at the same site, it is believed that this complex (and likely the whole settlement) was damaged by the earthquake that hit the Levant at the end of the Umayyad period ca. 749 A.D. Shortly thereafter, the church underwent minor modifications. A few roughly constructed walls were unearthed in the western and northern parts of the church. These are constructed directly on top of the mosaic pavements, and their remains include worked stones that suggest they were once parts of doorjambs and lintels. The construction of these walls directly on the mosaics might indicate that the church was either partially or completely cleaned 
of the collapse deposits and a portion of it was then subdivided into smaller rooms by means of partition walls. Consequently, it seems to us that some of the survivors of the earthquake tried to create a temporary living space for themselves before finally moving to settle elsewhere.

Antiquities looting: The crypt was heavily vandalized and looted in antiquity, and we believe that this happened in the eighth century, shortly after the destruction of the town. Furthermore, we believe that the procedures of looting the crypt were as follows: The looters first dug a trench through the destruction layers of the church down to the squarish opening, after which they destroyed the stone slab blocking this opening. Next, they entered the crypt and carefully collected all visible funerary objects. After this, they first removed the human remains from the southern grave, dumping them in its western end in order to search among them for other valuable objects. They then did the same thing with the majority of the skeletal remains of the other two graves, likewise dumping them randomly in the southern grave. At the conclusion of the operation, the crypt raiders left the vandalized tomb completely open.

Dismantling the walls: The area of the church and its environs have been subjected to the dismantling of the ancient walls. In 1850, the Greek Orthodox community of Ramallah robbed out a large number of trimmed stones in order to build a new church and few church-owned residential structures in the historic core of Ramallah. Furthermore, in 1998 two column bases were transported from the site and installed in an entertainment establishment in Ramallah. Finally, in 2008-2009 the owner of the gas station located in the middle of the Khirbet used ancient building stones taken from the area of the church to raise the upper edges of the Byzantine pool located within the area of his establishment (Al-Houdalieh, 2014: p. 191-196).

Agricultural practices: In an earlier interview carried out by the author in 2013 with Father Nicola, the priest of A'in Arik Greek Orthodox Church, he provided me with the following information: This Khirbet was actively cultivated up until the end of the 1960s. It was planted in seasonal crops, and the light plows employed, drawn by horses or donkeys, penetrated the ground to a depth of $25 \mathrm{~cm}$ or so. Moreover, to prepare the land for cultivation, the farmers used to collect the surface stones and gather them in heaps, or they used them in terrace construction both on the site and in its environs (Al-Houdalieh, 2014: p. 191). At the beginning of the third excavation campaign, we removed a section of the Ottoman-period agricultural terrace built on the southern part of the site, in order to unearth the remainder of the western church and also to investigate generally the area beneath this large heap. The removed segment of this dry-stone terrace wall was $35 \mathrm{~m}$ long $\times 1.5 \mathrm{~m}$ to $2 \mathrm{~m}$ high $\times 1.5 \mathrm{~m}$ to $3 \mathrm{~m}$ in thickness. This heap of stones was found to consist mostly of unworked small-and medium-sized stones. However, it also included a significant number of large, well-dressed stone elements: fragments of column drums; a column base; carved stones that were apparently parts of doorways, lintels or sills; other stone slabs of various sizes; and figurative pieces, among others. We believe that the stones of this heaped terrace wall were accumulated over a long period of time, connected with the continuous agricultural activities carried out on the site. This practice not only changed the physical appearance of the cultural landscape but also clearly placed the architectural remains of the site at risk.

The depth of the earthen deposits found above the mosaic floor pavement of the church ranged from a mere $0.2 \mathrm{~m}-0.25 \mathrm{~m}$ in the eastern part to between $0.5 \mathrm{~m}$ and $1 \mathrm{~m}$ in the western part. Not surprisingly then, characteristic plow marks were clearly visible in many areas of the bedding layer of the mosaics (Figure 16). Plowing has contributed dramatically to the damage to the architectural remains of this complex. Indeed, the consequences of plowing are more dire on the eastern area of the church, which stood higher above the surrounding terrain. Thus the process of plowing there precipitated greater erosion as new, deeper layers were disturbed with each subsequent plowing. The plowing carried out in this eastern area of the complex led to the total destruction of the mosaic floors, including the bedding layer, nucleus and statumen.

Tree roots: The Khirbet is planted with olive trees. In general, the planting of trees threatens the archaeological remains because, first, the farmers must dig a pit $0.35 \mathrm{~m}$ to $0.50 \mathrm{~m}$ deep in order to set the sapling, disturbing the uppermost cultural deposits. Moreover, the growing roots of the trees inevitably disturb the archaeological remains below and around it. Three large olive trees are flourishing within the ruins of the eastern church, and as the excavation proceeded we encountered numerous roots, both major and minor, extending $5 \mathrm{~m}$ to $8 \mathrm{~m}$ in all directions from the tree trunks. Some of these root systems cover the mosaics, while others penetrate and/or extend beneath the mosaic pavements. These roots have thus caused changes in the soil structure, cracks and bulges in the pavements, detachments between mosaic layers, deterioration of the mortar between tesserae, and of course many detached tesserae. 


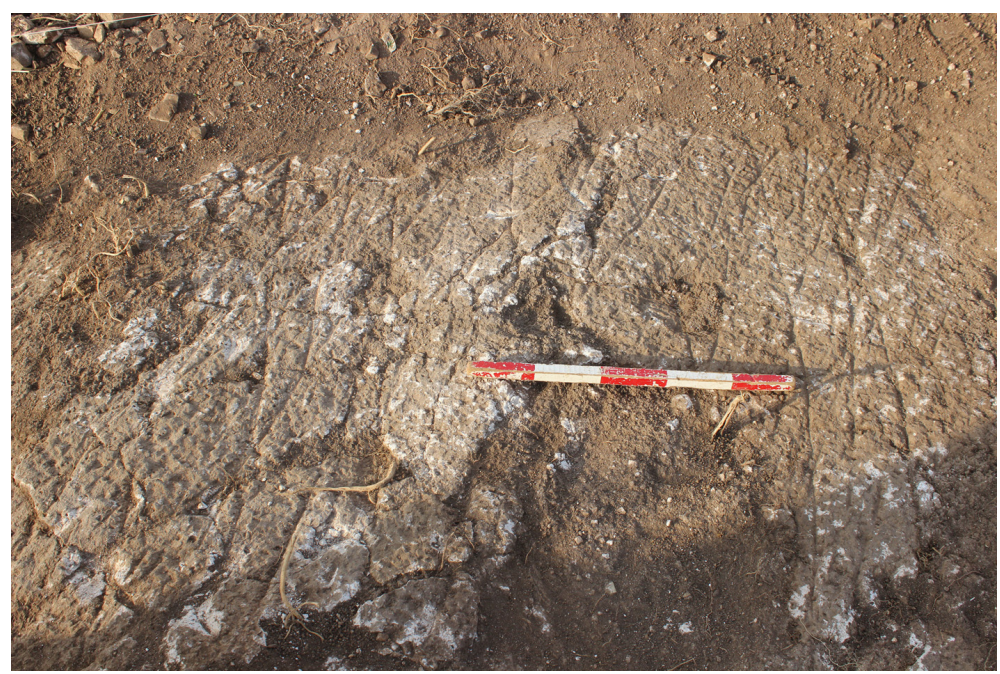

Figure 16. Plow marks in the southern aisle, looking north (photo by S. AlHoudalieh).

\section{Conclusion}

Before the start of our long-term project at Khirbet et-Tireh in 2013, the site had been totally neglected and ignored, considered as having no cultural value. Thus, it never attracted the attention of any archaeologists who might explore or safeguard it, either the Israeli Staff Officer for Archaeology or, post-Oslo, the Palestinian Ministry of Tourism and Antiquities. Consequently, it has been extremely misused over the past few decades. As a result of several urban development projects, nearly three-fourths of the greater site was destroyed down to the bedrock surface-or even below it, without any kind of documentation. The results of our three excavation campaigns on the protected part of the site (6000 square meters) prove that such neglected and ignored sites can be rich indeed in archaeological remains, sometimes finds of great importance. They can produce valuable information about ancient civilizations and thus it is worth all the efforts and resources required to protect them, for the benefit of both the present and future generations.

Due to the location of the site in an urban setting, and because of the easy access to it, a large number of people have visited us during the course of our excavation work. These interested persons have included both Palestinians and foreigners, one-time and repeat visitors, individuals and groups, and those of various ages and education levels. We recognized from the beginning of our first excavation season (2013) that such encounters could be useful in a number of ways: to engage the local community in safeguarding Palestine's archaeological resources generally, to educate the visitors about the archaeological history of our particular site, and to raise awareness about the importance of such discoveries to people's cultural identity and for the economic recovery of the country. Therefore, I appointed one of my excavation team to accompany people on their visits to the site, provide some explanation of our discoveries, and then engage in dialogue with them about the future of Palestine's cultural heritage, focusing on Khirbet et-Tireh as an example. Several of our visitors have in fact participated in the excavation as volunteers for one day or more, and positive dialogue between them and our excavation team always ensued. To further reach a broad cross-section of the local Ramallah population, we organized several workshops and seminars at different institutions, including schools located in the et-Tireh quarter, the Ramallah Women's Training Centre, Ramallah Municipality, the Ministry of Local Government, and youth clubs. Furthermore, at the end of each excavation and conservation campaign a structured site presentation was organized, with 70 to 100 persons invited to each event, including presidents of academic institutions, foreign consuls, clergy, representatives of Palestinian government ministries, intellectuals, school teachers and students, and media agencies.

The relatively large size of Khirbet et-Tireh, the fortification system, and the multiple architectural remains unearthed here, including two churches, taken together all indicate that it was a main town with significant religious value during the Byzantine-Umayyad era. Both churches follow a basilical plan, are built with stones laid immediately on top of the bedrock, are accessed by the same street, and their floor levels lie at the same elevation. Based on the coins recovered (Figure 17) and our reading of the pottery sherds found in several different 


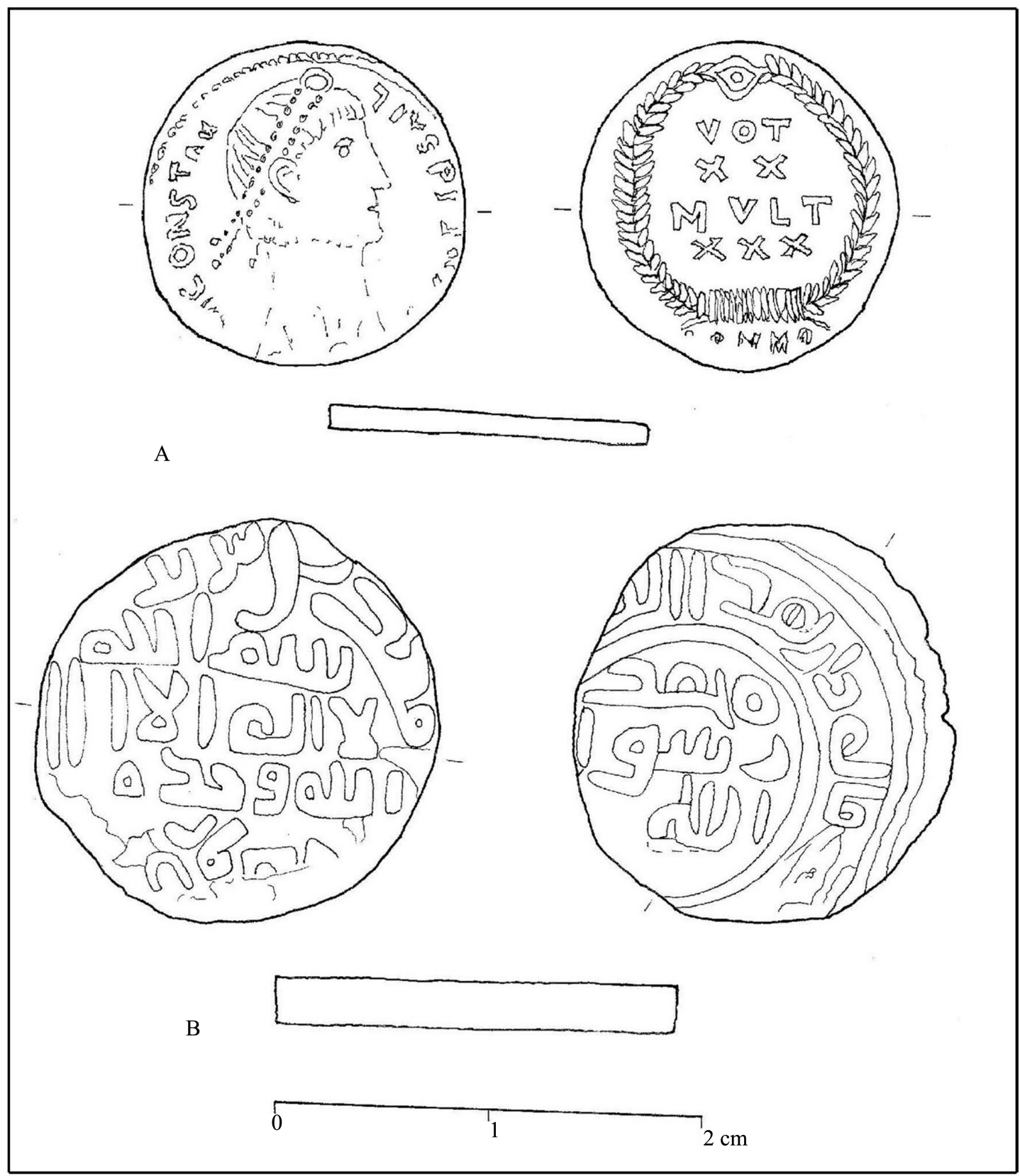

Figure 17. Coins found in the eastern church at Khirbet et-Tireh: (A) Early Byzantine period (Constantius II); and, (B) Umayyad period (drawing by I. Iqtait).

undisturbed loci (excavated both inside the churches and in their immediate surroundings), we conclude that the two churches were constructed at more or less the same time and were in use throughout the $4^{\text {th }}-5^{\text {th }}$ centuries until the end of the Umayyad period.

Until now, we do not know why Khirbet et-Titeh had two churches functioning during the same time period. Indeed, I agree with Jodi Magness' suggestions when she tried to answer the same question regarding the existence of multiple contemporaneous churches in Byzantine-era sites, saying "perhaps the churches had different functions $[\ldots]$ perhaps they were used on different occasions, or perhaps they served different denominations with distinctive liturgies” (Magness, 2012: p. 341). However, the larger size of the eastern church of Khirbet etTireh, its well-cut, well-dressed stones, and the decorative patterns of its floor pavements-all may indicate that this church somehow enjoyed greater importance than the western one. 


\section{Acknowledgements}

We are grateful to Al-Quds University and the Greek Orthodox Patriarchate for their generous financial assistance, which allowed for the further excavation and conservation of Khirbet et-Tireh over the summer of 2015, and to the Palestinian American Research Centre (PARC) for its financial assistance, which has made possible the publication of this research. I am indebted also to my B.A. archaeology students for their tireless efforts over the course of the excavation season. Thanks are also extended to Osama Hamdan, Raed Khalil, Rafat Khateeb, and Wisal Musa for their skilled, professional conservation of the unearthed mosaic pavements of the church. Finally, I would like to thank Tom Powers for his constructive proofreading and comments on the draft of this work.

\section{References}

Al-Houdalieh, S. (2014). The Byzantine Church of Khirbet et-Tireh. Journal of Mediterranean Archaeology and Heritage Studies, 2, 188-208. http://dx.doi.org/10.5325/jeasmedarcherstu.2.3.0188

Figueras, P. (1995). Monks and Monasteries in the Negev Desert. Liber Annuus, 45, 401-450.

Haines, R. (1960). A Byzantine Church at Khirbet al-Karak (Vol. 85, pp. 4-28). The University of Chicago Oriental Institute Publications, Chicago, IL: The University of Chicago Press.

Hizmi, H. (1990). The Byzantine Church at Khirbet el-Beiyudat: Preliminary Report. In G. C. Bottini, L. De Segne, \& E. Alliata (Eds.), Christian Archaeology in the Holy Land, New Discoveries (pp. 245-264). Jerusalem: Franciscan Printing Press.

Korzhenkov, A., \& Mazor, E. (2014). Archaeoseismological Damage Pattern at the Ancient Ruins of Rehovot-ba-Negev, Israel. Archaeologischer Anzeiger, 2014/1, 75-92.

Margalit, S. (1995). The Binated Churches and the Hybrid Binated Church Complexes in Palestine. Liber Annuus, 45, 357400.

Magness, J. (2012). The Archaeology of the Holy Land from the Destruction of Solomon's Temple to the Muslims Conquest. Cambridge: Cambridge University Press.

Negev, A. (1993). The Cathedral at Haluza (Elusa). In Y. Tsafrir (Ed.), Ancient Churches Revealed (pp. 286-293). Jerusalem: Israel Exploration Society.

Oren, E. (1993). A Christian Settlement at Ostrakine in North Sinai. In Y. Tsafrir (Ed.), Ancient Churches Revealed (pp. 305-314). Jerusalem: Israel Exploration Society.

Ousterhout, R. (2001). The Architecture of Iconoclasm: The Buildings. In A. Bryer, \& J. Haldon (Eds.), Byzantium in the Iconoclast Era (ca 680-850): The Sources, an Annotated Survey (pp. 3-36). Burlington: Ashgate Publishing Company.

Patrich, J., \& Tsafrir, Y. (1993). A Byzantine Church Complex at Horvat Beit Loya. In Y. Tsafrir (Ed.), Ancient Churches Revealed (pp. 265-272). Jerusalem: Israel Exploration Society.

Schick, R. (1995). The Christian Communities of Palestine from the Byzantine to Islamic Rule: A Historical and Archaeological Study in Late Antiquity and Early Islam. Princeton, NJ: The Darwin Press.

Schick, R. (1998). Archaeological Sources for the History of Palestine: Palestine in the Early Islamic Period: Luxuriant Legacy. Near Eastern Archaeology, 61-62, 74-108. http://dx.doi.org/10.2307/3210639

Schick, R., \& Suleiman, E. (1991). Preliminary Report on the Excavations of the Lower Church at el-Quweisma, 1989. ADAJ, 35, 325-340.

Tzaferis, V. (1993). The Early Christian Monastery at Kursi. In Y. Tsafrir (Ed.), Ancient Churches Revealed (pp. 77-82). Jerusalem: Israel Exploration Society. 